\title{
HUKUM INTERNASIONAL TENTANG GENOSIDA DALAM PERSPEKTIF FIKIH DAULIY
}

\author{
Nimas Masrullail Miftahuddini Ashar \\ Sekolah Dasar Baitu IImin Jl. Girilaya 68 Surabaya |cazza_ryn@yahoo.com
}

\begin{abstract}
This article discusses about the genocide in international law on the dauliy jurisprudence perspective. International law governs the genocide crime in the Rome Statute which is applied for the state parties. The Rome Statute becomes the basis for the International Criminal Court (ICC) which is responsible for handling the case of genocide and other cases listed in the Rome Statute. Based on article 77 of the Rome Statute, genocide perpetrator will be liable to imprison of not more than 30 years, or a lifetime (under certain condition). In addition, the offender will be liable to fine and confiscation. Based on this, international law governing the genocide can be quite fair because there is no difference in the position of judge and imposing sanction, but when it is viewed from the dauliy jurisprudence perspective, sanction given to the perpetrator of genocide is considered not to be commensurate with the conducted crime.
\end{abstract}

Keywords: Dauliy Jurisprudence, Genocide, International Law

Abstrak: Artikel ini membahas tentang hukum internasional tentang genosida dalam perspektif fikih dauliy. Hukum internasional mengatur tentang tindak kejahatan genosida di dalam statuta roma yang berlaku untuk negara-negara pihak perjanjian. Statuta Roma menjadi dasar terbentuknya Pengadilan Kriminal Internasional (ICC) yang bertugas menangani kasus genosida dan beberapa kasus lain yang tercantum di dalam Statuta Roma. Berdasarkan pasal 77 Statuta Roma, pelaku tindak kejahatan genosida akan dikenakan sanksi berupa penjara yang tidak lebih dari 30 tahun, atau seumur hidup (dalam kondisi tertentu), selain itu pelaku akan dikenakan sanksi berupa denda dan penyitaan. Berdasarkan hal tersebut, hukum internasional yang mengatur tentang genosida dapat dikatakan cukup adil karena tidak ada perbedaan kedudukan dalam mengadili dan memberikan sanksi, namun bila dilihat dari fikih dauliy, sanksi yang diberikan pada pelaku tindak kejahatan 
genosida dinilai tidak cukup imbang dibandingkan dengan tindakan yang dilakukannya.

Kata Kunci: Fikih Dauliy, Genosida, Hukum Internasional

\section{Pendahuluan}

Kejahatan yang dilakukan terhadap umat manusia adalah istilah yang terdapat pada hukum internasional yang mengacu pada tindakan pembunuhan massal dengan penyiksaan terhadap tubuh dari orang-orang, sebagai suatu kejahatan penyerangan terhadap orang lain atau sekumpulan masyarakat tertentu. para pakar dan sarjana hubungan internasional secara luas telah menggambar "kejahatan terhadap umat manusia" sebagai tindakan yang sangat keji pada suatu skala yang sangat besar, yang dilaksanakan untuk mengurangi ras manusia secara keseluruhan. Kejahatan yang dilakukan terhadap umat manusia yang berhubungan dengan ras tertentu ini dilakukan atas dasar kepentingan politis, seperti yang pernah terjadi di Jerman saat pemerintahan masih berada di tangan Adolf Hitler, seorang politisi Jerman dan ketua partai Nazi. Sekitar 11 hingga 17 juta jiwa beragama Yahudi menjadi korban penyiksaan dan genosida. Ada beberapa cara yang digunakan pasukan Adolf Hitler untuk membunuh mereka, diantaranya adalah memasukkan mereka ke dalam satu ruangan gelap dan tertutup dan memenuhi ruangan tersebut dengan gas beracun. Sedangkan anak-anak dibunuh dengan cara yang berbeda, yakni dengan cara medis berupa suntik mati atau euthanasia. ${ }^{1}$ Tindak kejahatan genosida juga pernah terjadi di Rwanda selama 100 hari, dimulai dari tanggal 6 April hingga pertengahan Juli tahun 1994. Kurang lebih 1 juta warga suku Tutsi terbunuh oleh suku Hutu. ${ }^{2}$

Kasus pemusnahan seluruh ras tertentu yang dilakukan atas dasar kepentingan politis ini diyakini pertama kali terjadi di Turki

\footnotetext{
' Henry Friedlander, The Origin of Nazi Genocide, (North Carolina: Univ of North Carolina Press, 1997), $86-87$.

2 Frank Spalding, Genocide in Rwanda, (New York: The Rosen Publishing Group, Inc., 2009), 6.
}

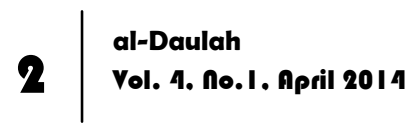


pada Perang Dunia I, yaitu pada tahun 1915-1918. Perancis telah memaksa warganya untuk meyakini bahwa pembunuhan massal warga Armenia di Turki merupakan pembasmian etnik. Diperkirakan kurang lebih 300.000-1.500.000 orang Armenia tewas dalam pembunuhan massal dan pengusiran bangsa Armenia (orang-orang Yahudi yang dibantai), namun Turki menyangkalnya dan berkata bahwa itu adalah kerusuhan berdarah di tengah Perang Dunia I. ${ }^{3}$ Kejadian ini mengharuskan PBB untuk menyusun sebuah perjanjian antar bangsa dan negara di seluruh dunia untuk menghindarkan kejadian yang serupa. Maka, pada tanggal 9 Desember 1948, PBB mengesahkan konvensi yang bernama "Convention on the Prevention and Punishment of the Crime of Genoside" atau yang biasa disebut dengan konvensi genosida. Konvensi genosida mulai berlaku pada tanggal 12 Januari 1961. ${ }^{4}$ Konvensi tersebut merupakan konvensi pertama yang mengatur tentang genosida dan berlaku di seluruh dunia.

Tindak kejahatan genosida kembali dilakukan terhadap orang Yahudi, Gipsi, dan suku bangsa Slavia oleh kaum Nazi Jerman pada Perang Dunia II, diikuti dengan beberapa kejadian serupa di tahun-tahun berikutnya. ${ }^{5}$ Pada tahun 2002, perjanjian tentang genosida kembali dibuat di dalam Statuta Roma. Statuta Roma disahkan pada tanggal 1 Juli 2002. 120 negara telah menjadi bagian dalam pihak Statuta Roma hingga tanggal 1 Februari 2012. Negaranegara tersebut yakni; 33 negara dari Afrika, 18 negara dari AsiaPasifik, 18 negara dari Eropa Timur, 26 negara dari Amerika Latin dan Kepulauan Karibia, dan 25 negara dari Eropa Barat dan Amerika Utara. ${ }^{6}$ Statuta Roma mulai berlaku sejak tanggal disahkannya hingga sampai saat ini.

Dalam pasal 6 Statuta Roma disebutkan bahwa:

${ }^{3}$ Ditto Wicaksono, Keberlakuan Konvensi Genosida 1948 terhadap Kasus Genosida di Turki, http://ditto-w.blogspot.com/2008/I I diakses 26 Maret 2013.

${ }^{4}$ Ian Brownlie, Basic Document on Human Rights, (Jakarta: UI-Press, 1993), 39.

${ }^{5}$ Wikipedia, Genosida, http://id.wikipedia.org/wiki/Genosida diakses 28 Maret 2013.

${ }^{6}$ ICC-CPI, Understanding the International Criminal Court (Netherlands: Facts sheets, 20 I I) I 3. 
For the purpose of this statue "Genocide means any of the following acts commited with intent to destroy, in whole or in part, a national, ethnical, racial or religius group, as such:

1. Killing members of the group;

2. Causing serious bodily or mental harm to members of the group;

3. Deliberately inflicting on the group conditions of life calculated to bring about its physical destruction in whole or in part;

4. Imposing measures to intended to prevent birthd within the group;

5. Forcibly transfering children of the group to another group. ${ }^{7}$

Islam mengenal istilah hubungan internasional dengan istilah yang berbeda, yakni "fikih dauly". Fikih dauly merupakan hukum yang mengatur negara dalam hal hubungan internasional masalah teritorial, nasionalitas, ekstradisi, tahanan, pengasingan, tawanan politik, dan pengusiran warga negara asing. Selain itu, fikih dauly juga membahas masalah kaum zimmi, perbedaan agama, akad timbal balik dan sepihak dengan kaum zimmi, hudud dan qisas. ${ }^{8}$ Islam telah mengenal hubungan internasional antar negara, yakni selama 700 tahun Islam pernah berkuasa dan bersentuhan dengan budaya Romawi Timur di Damaskus, Mesir, hingga ke Andalusia. ${ }^{9}$ Selain hubungan internasional yang baik, Islam juga memiliki tokoh hubungan internasional, yang paling terkenal diantaranya adalah Muhammad bin Hasan al-Syaibani (132 H-189 H). Pemikiran beliau mengenai hubungan internasional ditulis di dalam kitabnya yang berjudul "Al-Siyar Al-Kabir" dan juga "AlSiyar Al-Sagir.10 Kitab tersebut membahas masalah jihad dan hubungan antar muslim dan non-muslim secara luas.

\footnotetext{
${ }^{7}$ Statuta Roma, pasal 6 ( 17 Juli 1998).

8 Solihat, Hubungan Internasional dalam Fiqh Siyasah, http://majelispenulis.blogspot.com/20 I2/05/hubungan-internasional-dalam-figh.html, diakses 28 Mei 2012.

9 A.Djazuli, Fiqh Siyasah: Implementasi Kemaslahatan Umat dalam Rambu-Rambu Syariah, (Jakarta: Kencana Prenada Media Group, 2009), 120.

${ }^{10}$ lbid., I2I.
} 
Tindak kejahatan terhadap umat manusia berupa genosida memang tidak dikenal di dalam Islam. Islam hanya mengenal istilah al-Jinayah dan al-Jarimah, atau di dalam peristiwa pembunuhan disebut "al-qatlu". Selain itu, Islam juga mengenal adanya perang dan damai dalam hubungan antar negara. Islam sangat mengecam tindak pidana yang berkaitan dengan nyawa seseorang. Pendapat ini diperkuat dengan firman Allah yang berbunyi :

"Oleh karena itu Kami tetapkan (suatu hukum) bagi Bani Israil, bahwa: Barangsiapa yang membunuh seorang manusia, bukan karena orang itu (membunuh) orang lain, atau bukan karena membuat kerusakan dimuka bumi, maka seakan-akan Dia telah membunuh manusia seluruhnya, dan barangsiapa yang memelihara kehidupan seorang manusia, maka seolah-olah Dia telah memelihara kehidupan manusia semuanya. Dan Sesungguhnya telah datang kepada mereka Rasul-rasul Kami dengan (membawa) keteranganketerangan yang jelas, kemudian banyak diantara mereka sesudah itu sungguh-sungguh melampaui batas dalam berbuat kerusakan dimuka bumi."11

Jika ayat di atas memberikan gambaran tentang pembunuhan secara tunggal, genosida merupakan tindakan melenyapkan nyawa satu bangsa atau suku yang dilakukan oleh bangsa atau suku lainnya yang berhubungan dengan masalah politis. Tindakan ini bisa saja terjadi di dalam ruang lingkup satu negara dan bisa pula melibatkan lebih dari satu negara yang mengakibatkan rusaknya suatu hubungan internasional antar negara tersebut.

Islam memiliki ketentuan sendiri dalam memberikan sanksi pidana bagi pelaku tindak kejahatan, namun Islam juga tidak melarang adanya suatu perjanjian antar negara demi terciptanya suatu kedamaian dunia. Hal ini diperkuat dengan perintah Imam Ali bin Abi Thalib ketika menjadi khalifah yang pernah

"' Departemen Agama RI, Al-Qur'an dan Terjemahannya, (Bandung: CV Penerbit Diponegoro, 2006), 113.

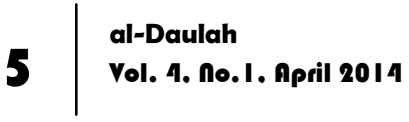


memerintahkan kepada an-Nakha'i, salah seorang panglima perangnya, sebagai berikut:

"Di dalam membuat perjanjian dan memberi keamanan tidak boleh dicampuri oleh kecurangan, kesewenangan, dan penipuan. Jangan anda membuat perjanjian yang dapat diputar balikkan dan jangan pula mencari kelemahan kalimat yang terdapat di dalam naskah perjanjian setelah perjanjian itu dibuat dengan penuh kesungguhan dan kepercayaan. Jangan meniru musuhmu (dalam membuat perjanjian) dan ingat selalu Tuhanmu."12

Dari paparan di atas, menarik untuk menganalisis fikih dauly terhadap hukum internasional tentang genosida.

\section{Hubungan Internasional dalam Fikih Dauly}

Para Ulama memiliki penjabaran tersendiri tentang Hubungan Internasional Islam, di antaranya adalah :

a. Muhammad bin Hasan al-Syaibani $(132 \mathrm{H}-189 \mathrm{H})$

Beliau menulis dalam kitabnya yang berjudul "Al-Siyar AlSagir" tentang hukum internasional Islam dan hukum internasional dalam Islam. Beliau berpendapat bahwa hukum internasional Islam bersumber pada $A l-Q u r^{\prime} a n$ dan $\mathrm{H}$ \{adis sebagaimana hukum Islam yang lainnya. Hukum internasional Islam juga mengenal metode ijma' dan qiyas dalam menyelesaikan suatu permasalahan atau sengketa. Sebaliknya, beliau menjabarkan hubungan internasional dalam Islam sebagai hubungan antara muslim dan nonmuslim dan juga hubungan antara negara Islam, negara perang, dan negara netral. Selain itu, hubungan internasional Islam juga membahas masalah negosiasi, delegasi, aturan berperang melawan musuh, dan juga tawanan perang. ${ }^{13}$

b. Taqiyuddin an-Nabhani $(1332 \mathrm{H}-1398 \mathrm{H})$

${ }^{12}$ A. Djazuli, Figh Siyasah, 137-138.

13 Muhammad bin Hasan al-Syaibani, Al-Siyar Al-Sagir, (Islamabad: Islamic Research Institute, 1998), 2 -5. 
Beliau menulis di dalam kitabnya "Al-Daulah Al-Islamiyah" bahwa hubungan internasional Islam berdiri di atas pemikiran yang baku dan tidak berubah. Pemikiran baku ini adalah penyebaran Islam ke semesta alam di semua umat dan bangsa. Adanya al-Daulah semata-mata untuk menerapkan Islam di dalamnya dan mengemban dakwahnya ke luar di seluruh penjuru alam. ${ }^{14}$

c. Abul A'la al-Maududi $(1321 \mathrm{H}-1397 \mathrm{H})$

Beliau berpendapat bahwa hukum internasional merupakan hukum yang terdiri dari konvensi dan perjanjian. Beliau juga berpendapat bahwa perjanjian adalah landasan utama dalam hubungan internasional dalam Islam. Beliau menyebut perjanjian ini dengan mitsaq. Mitsaq berarti semua pengertian yang menunjukkan bahwa satu negara tidak berperang dengan negara yang lainnya. Jika pengertian ini ada, sekalipun tidak terdapat perjanjian serikat secara tertulis atau pakta non-agresi secara tertulis, maka suatu negara Islam wajib memegang suatu mitsaq dengan negara yang bersangkutan. Namun, jika negara Islam terikat oleh perjanjian dengan bangsa tirani sehingga menimbulkan pelanggaran atas perjanjian tersebut, maka negara Islam yang bersangkutan dapat membatalkan perjanjiannya secara terbuka. ${ }^{15}$

Dari beberapa penjabaran di atas, maka hubungan internasional dalam fikih dauly berkaitan erat dengan perjanjian dalam kondisi perang dan damai, serta hubungan antara muslim dan non-muslim.

\section{Hukum Internasional dan Genosida}

${ }^{14}$ Taqiyuddin an-Nabhani, Al-Daulah Al-Islamiyah, (Bogor: Pustaka Thariqul 'Izzah, 2000), 211 212.

${ }^{15}$ Abul A'la al-Maududi, The Islamic Law and Constitution, (Bandung: Mizan, 1995), 209-2 10.

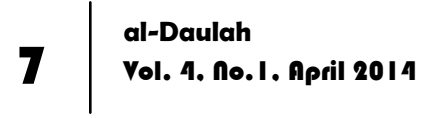


Menurut J.G Starke, hukum internasional adalah hukum yang mengatur tentang hubungan antar negara-negara satu sama lain, meliputi:

1. Peraturan hukum mengenai pelaksanaan fungsi lembagalembaga dan organisasi-organisasi itu masing-masing serta hubungannya dengan negara-negara dan individu-individu.

2. Peraturan hukum mengenai individu-individu dan kesatuankesatuan bukan negara sepanjang hak-hak atau kewajibankewajiban individu dan keta'atan itu merupakan masalah persekutuan Internasional. ${ }^{16}$

Hukum internasional juga merupakan hukum yang sah dan berlaku bagi seluruh negara di dunia. Setiap perjanjian yang dibuat dalam hukum perjanjian internasional, memiliki tema tersendiri dan wajib dipatuhi oleh setiap negara yang turut serta di dalamnya. Sayangnya, hukum internasional sendiri memiliki kelemahan, terlebih bila dibandingkan dengan hukum nasional. Kelemahannya adalah tidak adanya pemerintahan pusat (pemerintahan dunia) dan tidak adanya pemerintahan polisional untuk memaksakan berlakunya sanksi-sanksi serta keputusan dari Pengadilan Internasional, berbeda dengan hukum nasional yang memiliki hierarki secara subordinasi. Kelemahan inilah yang pada akhirnya akan menghambat pelaksanaannya. ${ }^{17}$

Dunia hukum internasional juga tidak lepas dari sengketasengketa internasional. Istilah sengketa-sengketa internasional tak hanya mencakup sengketa antar-negara, melainkan kasus lain yang berada dalam lingkup pengaturan internasional. Terdapat dua metode penyelesaian sengketa internasional:

1. Penyelesaian secara damai, yaitu apabila para pihak telah dapat menyepakati untuk menemukan solusi yang bersahabat.

2. Penyelesaian secara paksa atau kekerasan, yaitu apabila solusi yang dipakai atau dikenakan adalah melalui kekerasan. ${ }^{18}$

${ }^{16}$ T. May Rudy, Hukum Internasional I, (Bandung: PT. Refika Aditama, 2006), I.

${ }^{17} \mathrm{lbid}$, , 6-7.

${ }^{18}$ J.G Starke, Pengantar Hukum Internasional 2, (Jakarta: Sinar Grafika, 1997), 645-646.

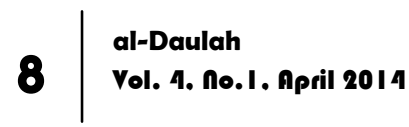


Saat ini, beberapa negara lebih menyelesaikan sengketa internasional secara damai dengan menyerahkan penyelesaian masalah tersebut ke organisasi PBB atau ke Pengadilan Internasional. Bagi mereka, menyelesaikan sengketa secara damai dengan mengadakan perjanjian internasional lebih baik daripada menyelesaikan sengketa dengan kekerasan. Termasuk dalam menyelesaikan kasus genosida dalam hukum internasional.

Genosida diatur di dalam Statuta Roma bersamaan dengan peraturan tentang kejahatan terhadap kemanusiaan, kejahatan perang, dan kejahatan agresi.

Dalam pasal 6 Statuta Roma disebutkan bahwa genosida merupakan suatu tindakan yang dilakukan secara sistematis dengan tujuan menghancurkan atau memusnahkan seluruh atau sebagian bangsa, etnis, ras, atau kelompok, seperti:

1. Membunuh anggota kelompok,

2. Menimbulkan penderitaan fisik atau mental yang berat terhadap anggota kelompok,

3. Sengaja menciptakan kondisi kehidupan kelompok yang mengakibatkan kemusnahan secara fisik, baik keseluruhan atau sebagian,

4. Memaksa tindakan-tindakan yang bertujuan mencegah kelahiran di dalam suatu kelompok,

5. Memindahkan secara paksa anak-anak dari satu kelompok ke kelompok lainnya. ${ }^{19}$

Dilihat dari pengertian genosida yang tercantum dalam Statuta Roma pasal 6, maka unsur-unsur kejahatan genosida secara umum adalah ${ }^{20}$ :

1. Korban berasal dari bangsa, etnis, ras, atau agama tertentu,

2. Pelaku berniat untuk menghancurkan seluruh atau sebagian kelompok bangsa, etnis, ras atau agama tertentu.

Selanjutnya, bila melihat dari setiap kata dalam pengertian genosida yang tercantum dalam Statuta Roma pasal 6, maka dapat

\footnotetext{
${ }^{19}$ Statuta Roma, Pasal 6 ( 17 Juli 1998)

${ }^{20}$ Rudi M. Rizki, Unsur-Unsur Genosida, (Yogyakarta, 2005).
}

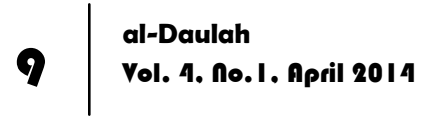


diketahui adanya beberapa unsur khusus di dalamnya. Unsurunsur khusus tersebut yakni:

1. "Melakukan pembunuhan terhadap anggota kelompok."

Unsur yang dapat diambil dari kalimat ini yakni; pelaku membunuh satu orang atau lebih dengan niat menyebabkan kematian.

2. "Menimbulkan penderitaan fisik atau mental yang berat."

Unsur yang dapat diambil dari kalimat ini yakni; pelaku menyebabkan luka fisik yang tampak pada anggota tubuh dan juga luka mental yang serius terhadap satu orang atau lebih. ICTR (International Criminal Tribunal for Rwanda) menjelaskan bahwa penderitaan yang berat terhadap fisik dan mental tidak perlu bersifat permanen dengan tujuan agar ancaman ketika interogasi juga masuk dalam unsur ini.

3. "Menciptakan kondisi kehidupan kelompok yang mengakibatkan kemusnahan secara fisik."

Unsurnya yakni; pelaku menibulkan kondisi kehidupan terhadap satu orang atau lebih dan kondisi tersebut dapat diperhitungkan akan mendatangkan kehancuran fisik terhadap kelompok tersebut, seluruhnya atau sebagian. Segala jenis tindakan yang mengakibatkan meninggalnya orang secara perlahan juga dapat dikategorikan dalam hal ini. Contoh dari unsur ini adalah perkosaan, membuat penduduk kelaparan, kurangnya fasilitas tempat berteduh yang layak, dipaksa melakukan pekerjaan berat baik fisik maupun mental, mengurangi pelayanan kesehatan sampai di bawah minimum, dan pengusiran paksa.

4. "Mencegah kelahiran."

Unsur yang didapat dari kalimat ini adalah pelaku memaksakan tindakan yang dimaksudkan untuk mencegah kelahiran tersebut. Tindakan-tindakan tersebut mencakup tindakan: sterilisasi, aborsi paksa, pemisahan pria dan wanita, dan menghambat perkawinan. 
5. "Memindahkan anak-anak secara paksa dari satu kelompok ke kelompok lain."

Unsur yang didapat dari pengertian ini adalah; pelaku memindahkan secara paksa satu atau lebih anak-anak dari suatu kelompok ke kelompok lain. Anak-anak yang dimaksud di sini adalah korban yang berusia di bawa 18 tahun dan pelaku mengetahui bahwa korban berusia di bawah 18 tahun. Pemindahan anak-anak secara paksa tersebut dapat berakibat serius terhadap masa depan dan kelangsungan terhadap suatu kelompok. ICTR menjelaskan bahwa tindakan ini juga mencakup tindakan ancaman atau trauma yang dapat mengarah pada pemindahan anak-anak secara paksa. ${ }^{21}$

Ada beberapa kejadian yang ditetapkan dunia sebagai kasus genosida, dimulai dari pembunuhan massal pertama yang dilakukan oleh bangsa Yahudi terhadap penduduk Kanaan pada milenium pertama sebelum masehi, kemudian diikuti oleh pembantaian-pembantaian lainnya yang kemudian ditetapkan oleh dunia sebagai genosida. Genosida terbesar yang pernah dicatat oleh sejarah dunia adalah pada masa pemerintahan Kolonial Raja Leopold II dari Belgia, ia adalah penguasa yang menerapkan sistem kerja paksa, pembunuhan massal dan penyiksaan. Perkiraan jumlah korban sekitar 30 juta, mulai dari tahun 1885 hingga abad ke-20. Populasi Kongo menurun dari sekitar 30 juta hingga di bawah 9 juta selama waktu dari kejaman tersebut. ${ }^{22}$

Untuk menyelesaikan kasus genosida, pada tanggal 9 Desember 1948, PBB membuat ketentuan hukum tentang genosida yang pertama, yakni, "Convention on the Prevention and Punishment of the Crime of Genocide", ditandatangani oleh 45 negara dan terdapat 85 ratifikiasi serta penambahan. Konvensi ini mulai

\footnotetext{
${ }^{21}$ Ibid.

22 Ricobain, Pembantaian atau Genosida Terbesar Dalam Sejarah, http:www. ricostrada.com/sejara/pembantaian-atau-Genosida-terbesar-dalam-sejarah, diakses 28 Maret 2013.
}

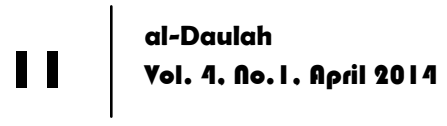


berlaku pada tanggal 12 Januari 1961. ${ }^{23}$ Konvensi ini terdiri dari 19 pasal dan khusus membahas masalah genosida.

Kemudian, pada 17 Juli 1998, dibuat peraturan baru tentang genosida, yakni Statuta Roma. Statuta Roma merupakan hasil dari beberapa upaya untuk menciptakan sebuah pengadilan internasional. Statuta Roma dibuat dengan tujuan untuk menyelaraskan hukum perang dan membatasi penggunaan senjata berteknologi maju yang terjadi pasca Perang Dunia I dan Perang Dunia II. Prioritas utamanya adalah untuk mengadili individu yang bertanggung jawab atas kejahatan teradap kemanusiaan. Dengan adanya Statuta Roma, para pelaku tindak kejahatan teradap umat manusia tidak dieksekusi di kotak umum atau dikirim ke perkemahan penyiksaan, namun mereka diperlakukan sebagai penjahat dengan sidang reguler, hak untuk membela diri dan praduga tak bersalah. ${ }^{24}$ Statuta Roma mulai diberlakukan pada tanggal 1 Juli tahun 2002 dan menjadi dasar dibentuknya Pengadilan Kriminal Internasional (International Criminal Court) pada tahun 2002. Pengadilan Kriminal Internasional merupakan sebuah "tribunal" permanen untuk menuntut individual yang melanggar pada ketentuan Statuta Roma untuk membantu sistem yudisional nasional yang telah ada. Oleh karena Statuta Roma menjadi dasar berdirinya International Criminal Court, maka seluruh kejahatan yang diatur di dalam Statuta Roma akan diadili di Pengadilan tersebut.

Yuridiksi ICC terbatas pada 4 hal; wilayah, waktu, materi perkara, dan perseorangan atau person. ICC bisa menjalankan fungsi dan kewenangannya di wilayah negara pihak dalam Statuta Roma, namun ICC juga dapat menjalankan kewenangannya di negara bukan pihak asalkan ada perjanjian.

\footnotetext{
${ }^{23}$ Ian Brownlie, Dokumen-Dokumen Pokok Mengenai Hak Asasi Manusia,, 39.

Wikipedia, Rome Statute of The International Criminal Court, http://en.wikipedia.org/wiki/Rome-Statute-of-The-International-Criminal-Court, diakses 16 Agustus 2013.
} 
Sedangkan sanksinya diatur dalam pasal 77 Statuta Roma yang berbunyi:

1. Subject to article 110, the Court may impose one of the following penalties on a person convicted of a crime referred to in article 5 of this Statute:

(a) Imprisonment for a specified number of years, which may not exceed a maximum of 30 years; or

(b) A term of life imprisonment when justified by the extreme gravity of the crime and the individual circumstances of the convicted person.

2. In addition to imprisonment, the Court may order:

(c) A fine under the criteria provided for in the Rules of Procedure and Evidence;

(d) A forfeiture of proceeds, property and assets derived directly or indirectly from that crime, without prejudice to the rights of bona fide third parties. ${ }^{25}$

Pasal tersebut menjelaskan bahwa pengadilan dapat menjatuhkan salah satu dari hukuman berikut pada para pelaku kejahatan yang tercantum dalam pasal 5 Statuta Roma. Opsi dari hukuman tersebut yakni:

1. Pemenjaraan untuk jangka waktu tertentu dan tidak boleh lebih dari 30 tahun, atau

2. Hukuman penjara seumur hidup dilihat dari besarnya kejahatan yang telah dilakukannya dan juga keadaan dari tiap individu terpidana.

3. Selain hukuman penjara, pengadilan juga dapat memberikan hukuman berupa:

4. Denda, berdasarkan kriteria yang diatur dalam peraturan prosedur dan bukti,

5. Disitanya dana, properti, juga aset yang diperoleh secara langsung atau tidak langsung dari kejahatan tersebut, tanpa

25 Statuta Roma, Pasal 77.

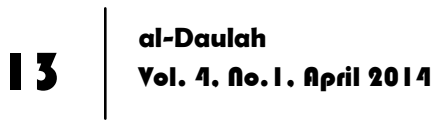


mengurangi hak-hak negara pihak perjanjian yang menjadi korban dalam kejahatan tersebut.

Dilihat dari pelaku tindak kejahatan internasional, Statuta Roma memberikan peraturan berupa pertanggungjawaban secara individual, sebagaimana yang tercantum di dalam pasal 25 . Selanjutnya, pada pasal 26 disebutkan bahwa pengadilan tidak memiliki wewenang untuk mengadili anak berusia di bawah 18 tahun ketika anak tersebut diduga melakukan tindak kejahatan. Selanjutnya, di dalam pasal 27 disebutkan bahwa Statuta Roma berlaku bagi siapa saja, tanpa memandang jabatan atau bangsa dari pelaku yang diduga melakukan tindak kejahatan tersebut.

Berdasarkan 3 pasal di atas, dapat disimpulkan bahwa, pertanggungjawaban perbuatan pidana dilakukan secara individu dan dihukum sesuai dengan gravitasi atau kadar perbuatannya, sedangkan tindak pidana yang dilakukan oleh warga negara atau pemimpin negara, tidak mempengaruhi tanggung jawab dan eksistensi dari negara tersebut di dalam hukum Internasional.

Hukuman atau sanksi yang dijatuhkan kepada pelaku tindak kejahatan genosida disesuaikan dengan tuntutan jaksa. Ketentuan ini tercantum di dalam Aturan Prosedur dan Bukti yang berbunyi:

Orders of forfeiture

1) In accordance with article 76, paragraphs 2 and 3, and rules 63, sub-rule 1, and 143, at any hearing to consider an order of forfeiture, Chamber shall hear evidence as to the identification and location of specific proceeds, property or assets which have been derived directly or indirectly from the crime.

2) If before or during the hearing, a Chamber becomes aware of any bona fide third party who appears to have an interest in relevant proceeds, property or assets, it shall give notice to that third party.

3) The Prosecutor, the convicted person and any bona fide third party with an interest in the relevant proceeds, property or assets may submit evidence relevant to the issue. 
4) After considering any evidence submitted, a Chamber may issue an order of forfeiture in relation to specific proceeds, property or assets if it is satisfied that these have been derived directly or indirectly from the crime. ${ }^{26}$

Aturan tersebut menjelaskan bahwa hakim menjatuhi hukuman berdasarkan bukti. Itikad baik juga mempengaruhi besarnya sanksi yang akan dijatuhkan kepada pelaku tindak kejahatan.

Setidaknya ada 18 kasus yang tercatat di dalam situs resmi International Criminal Court. Kasus-kasus tersebut terdapat di negara yang berbeda-beda. 6 kasus di Kongo, 1 kasus di Republik Afrika, 1 kasus di Uganda, 5 kasus di Darfur, Sudan, 2 kasus di Kenya, I kasus di Libya, dan 2 kasus di Pantai Gading. ${ }^{27}$ Di antaranya ada kasus yang telah dituntaskan, namun beberapa di antaranya masih ada yang belum tuntas, bahkan ada yang dinyatakan gagal oleh publik. Dalam 18 kasus tersebut yang berhasil diselesaikan salah satunya adalah kasis dengan nomor ICC-01/04-01/06. Thomas Lubanga Dylo adalah orang yang diadili di sini. Lubanga Dylo dituntut karena mendaftar dan merekrut anak-anak dibawah usia 15 tahun ke dalam Patriot Angkatan Untuk Pembebasan Kongo (Force Patriotique Pour La Liberation Du Congo) dan menggunakan mereka untuk berpartisipasi secara aktif dalam permusuhan atau konflik bersenjata mulai tanggal 1 September tahun 2002 sampai 13 Agustus 2003. Itu artinya, Lubanga Dylo dinyatakan melanggar pasal 8 ayat (2) (e) (vii) Statuta Roma. Pada tanggal 10 Juli tahun 2012, Trial Chamber I menghukum Lubanga Dylo dengan total hukuman 14 tahun penjara. Namun, ada juga kasus yang dinyatakan gagal oleh publik. Salah satunya adalah kasus dengan nomor ICC-02/0501/09. Kasus ini membawa nama Omar Hassan Ahmad bin al-

\footnotetext{
${ }^{26}$ International Criminal Court, Rules of Procedure and Evidences (UN: document, 200 I), Rule 147.

${ }^{27}$ International Criminal Court, www.icc-cpi.int, diakses I Juli 2013.
}

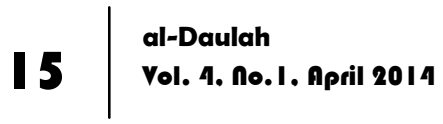


Bashir, presiden Sudan sejak 16 Oktober 1993 yang mendapatkan tuntutan berupa:

a. Lima (5) tuduhan kejahatan kemanusiaan yang merujuk pada pasal 7 ayat (1) (a), pasal 7 ayat (1) (b), pasal 7 ayat (1) (d), pasal 7 ayat (1) (f), dan pasal 7 ayat (1) (g),

b. Dua (2) tuduhan kejahatan perang yang merujuk pada pasal 8 ayat (2) (e) (i), dan pasal 8 ayat (2) (e) (v),

c. Tiga (3) tuduhan Genosida dengan merujuk pada pasal 6-a, pasal 6-b, dan pasal 6-c.

Kasus ini kemudian dikenal dengan sebutan pembantaian kaum berkulit hitam di Darfur oleh Milisi Janjaweed di Sudan yang terjadi pada tahun 2004. Publik menyatakan bahwa kasus ini gagal ditangani oleh ICC lantaran ICC sering menemukan jalan buntu dalam penyelesaian konflik tersebut. Penangkapan Omar alBashir akan berdampak pada situasi Sudan serta jaminan stabilitas domestiknya. Selain itu, adanya intervensi asing, khususnya negara-negara barat (Amerika Serikat dan Inggris), juga Cina, membuat konflik etnis tersebut tak kunjung usai. ${ }^{28}$

\section{Analisis Fikih Dauly terhadap Ketentuan Hukum Internasional yang Mengatur tentang Genosida}

Dalam pasal 6 Statuta Roma disebutkan bahwa genosida berarti suatu tindakan yang dilakukan secara sistematis dengan tujuan menghancurkan atau memusnahkan seluruh atau sebagian bangsa, etnis, ras, atau kelompok dengan beberapa kualifikasi dan unsur-unsurnya. Bila dilihat dari Fikih Jinayah, maka beberapa poin di atas dapat disamakan artinya dengan pembunuhan dan penganiayaan. Allah berfirman dalam Al-Qur'an surah Al-Maidah ayat 32 :

"Oleh karena itu, Kami tetapkan (suatu hukum) bagi Bani Israil, bahwa: Barangsiapa yang membunuh seorang manusia, bukan

\footnotetext{
28 Mas Isharyanto, Mengapa ICC Gagal Menangani Konflik Sudan?, http://isharyanto.wordpress.com/racikan-ilmiah/lentera-ide/mengapa-icc-gagal-menanganikonflik-sudan/diakses I Juli 20I3.
} 
karena orang itu (membunuh) orang lain, atau bukan karena membuat kerusakan dimuka bumi, maka seakan-akan Dia telah membunuh manusia seluruhnya. Dan barangsiapa yang memelihara kehidupan seorang manusia, maka seolah-olah Dia telah memelihara kehidupan manusia semuanya. Dan sesungguhnya telah datang kepada mereka Rasul-rasul Kami dengan (membawa) keteranganketerangan yang jelas, kemudian banyak diantara mereka sesudah itu sungguh-sungguh melampaui batas dalam berbuat kerusakan dimuka bumi." 29

Ayat di atas menegaskan bahwasannya barang siapa yang membunuh manusia, seolah-olah ia telah membunuh seluruh manusia. Bila ayat ini dilihat dari segi Ushul Fikih, maka ayat ini memiliki Mafhum Muwafagah bagian Fahwal Khitab, yang mana dapat dipahami "membunuh satu manusia dianggap telah membunuh seluruh manusia", tentu saja bila membunuh manusia dalam jumlah yang lebih banyak lagi maka hukumnya akan menjadi lebih berat.

Pembahasan fikih dauly tidak lepas dari pembahasan mengenai negara dan hak-hak warga negara yang ada di dalamnya. Abul A'la al-Maududi menetapkan hak-hak yang diperoleh oleh raykat dalam suatu negara, di antara hak-hak tersebut adalah:

1. Jaminan atas hidup dan harta kekayaan,

2. Perlindungan kehormatan,

3. Kepribadian dan jaminan kehidupan pribadi,

4. Jaminan kebebasan pribadi,

5. Hak untuk menentang tirani,

6. Hak untuk mengeluarkan pendapat,

7. Hak untuk berserikat,

8. Hak untuk mengeluarkan ucapan hati nurani dan keyakinan,

9. Perlindungan terhadap sentimen-sentimen keagamaan,

\footnotetext{
${ }^{29}$ Depag, Al-Qur'an dan Terjemahannya, 113.
} 
10. Perlindungan dari penghukum yang sewenang-wenang,

11. Hak atas kebutuhan-kebutuhan hidup pokok,

12. Persamaan kedudukan di hadapan hukum,

13. Penguasa kebal hukum,

14. Hak untuk menjauhi perbuatan dosa,

15. Hak untuk ikut serta dalam urusan negara.

Selain hak, warga negara juga berhak mendapatkan kebebasan ketika menempati suatu negara. Kebebasan-kebebasan yang dimiliki oleh warga negara adalah sebagai berikut:

1. Kebebasan individu atau kebebasan jiwa

2. Kebebasan tempat tinggal,

3. Kebebasan memiliki,

4. Kebebasan berkeyakinan,

5. Kebebasan berpikir,

6. Kebebasan belajar.

Di samping hak dan kebebasan, warga negara juga memiliki kewajiban yang harus dijalani, yakni kewajiban untuk patuh terhadap Kepala Negara dan melindungi negara. Sebaliknya, Kepala Negara wajib melindungi hak dan kebebasan rakyatnya agar tetap terpenuhi.

Dilihat dari definisi genosida yang tercantum di dalam Statuta Roma, maka genosida merupakan tindak kejahatan yang mana berakibat hilangnya hak-hak dan kebebasan rakyat dalam suatu negara. Apabila terjadi tindakan genosida dalam suatu negara atau suku atau bangsa tertentu, maka Kepala Negara wajib membela rakyatnya agar hak-hak rakyat dan kebebasan mereka tidak terenggut. Kepala Negara wajib memerintahkan rakyatnya untuk balas menyerang sebagai wujud atas pembelaan diri. Muhammad Hasan al-Syaibani berpegang pada prinsip pembalasan, yakni ketika sekelompok masyarakat mendapat perlakuan zalim, maka mereka boleh membalas perlakuan zalim tersebut untuk mempertahankan diri dan tidak akan dikenakan sanksi atasnya. 
Dilihat dari status kewarganegaraan pelaku tindak kejahatan genosida, maka tindak kejahatan genosida dapat dikategorikan menjadi 2 macam, yakni:

1. Tindak pidana politik (Jaraim Siyasiyyah), yakni ketika pelakunya berasal dari dalam negeri. Genosida terjadi di dalam keadaan (situasi) luar biasa, tepatnya dalam keadaan pemberontakan. Pelaku genosida lazimnya akan memusnahkan apa saja sebagai bentuk pemusnahan ras yang dimaksud. Abdul Qadir Audah menyebut pelaku tindak pidana politik ini sebagai "bugat".

2. Penyerangan terhadap bangsa atau suku tertentu, yang mana dapat dikategorikan dalam bidang peperangan. Hal ini terjadi ketika pelaku tindak kejahatan genosida berasal dari negara lain.

Selanjutnya, bila dianalisis dari ketentuan hukum yang mengatur genosida, Statuta Roma merupakan landasan hukum kedua setelah konvensi genosida yang mengatur tentang genosida. Perbedaannya adalah, di dalam konvensi genosida tidak diatur tentang sanksi yang harus diterima oleh pelaku tindak kejahatan genosida, konvensi genosida menyerahkan sepenuhnya kewenangan penyelesaian kasus tindak kejahatan genosida pada negara di wilayah tempat kejadian perkara, sebagaimana yang tercantum di dalam pasal 6 Konvensi genosida. Sedangkan di dalam Statuta Roma, pihak negara yang mengikat perjanjian bila terjadi tindak kejahatan genosida di negaranya, maka tindakan tersebut dapat diselesaikan di Pengadilan Kriminal Internasional yang berpusat di Den Haag. Jaksa bisa menerima tuntutan itu dari korban tindak kejahatan genosida, atau mengajukan tuntutannya sendiri ke pengadilan, sebagaimana yang tertera di dalam pasal 15 Statuta Roma. Pengadilan Kriminal Internasional (International Criminal Court) akan memeriksa perkara tersebut, dan bila tuntutan itu benar adanya, maka tersangka akan dikenakan sanksi yang tertera di dalam pasal 77 Statuta Roma berupa: 
1. Pemenjaraan dalam jangka waktu tertentu dan tidak boleh lebih dari 30 tahun, atau

2. Hukuman penjara seumur hidup dilihat dari besarnya kejahatan yang telah dilakukannya dan juga keadaan dari tiap individu terpidana.

Selain itu, pengadilan juga dapat menjatuhkan hukuman berupa:

1. Denda berdasarkan kriteria yang diatur dalam peraturan prosedur dan bukti, yakni pada pasa 51,

2. Disitanya dana, properti, juga aset yang diperoleh secara langsung atau tidak langsung dari kejahatan tersebut, tanpa mengurangi hak-hak negara pihak perjanjian yang menjadi korban dalam kejahatan tersebut.

Seperti yang dicantumkan dalam pasal 25, pertanggungjawaban tindak pidana genosida adalah per-individu, meskipun tindakan itu dilakukan secara berkelompok. Di dalam pasal tersebut juga menjelaskan bahwa, pertanggungjawaban secara individual pelaku tindak kejahatan genosida tidak mempengaruhi tanggung jawab negara dalam hukum internasional. Jadi, negara tersangka tetap tidak berkurang eksistensinya di dunia internasional. Selanjutnya, di pasal 26 dan 27 disebutkan bahwa Statuta Roma berlaku bagi siapa saja, tanpa memandang jabatan pelaku, kecuali anak berusia di bawah 18 tahun, karena pengadilan tidak mengadili anak berusia di bawah 18 tahun. Hukuman yang dijatuhkan kepada pelaku berdasarkan tuntutan dari jaksa atau korban, sebagaimana yang tercantum dalam aturan nomor 147 Aturan Prosedur dan Bukti. Selama hukuman tersebut tidak di luar pasal 77 Statuta Roma.

Dilihat dari pelaku tindakannya, maka sanksi yang dijatuhkan kepada pelaku tindak kejahatan genosida adalah sebagai berikut:

1. Hukuman mati dengan syarat yang sudah ditentukan oleh agama Islam. Sanksi ini diperuntukkan bagi pelaku tindak kejahatan genosida yang berasal dari dalam negeri dan 
dianggap sebagai bugat, atau pemberontak. Hal ini merujuk pada firman Allah Surah Al-Maidah ayat 33:

"Sesungguhnya pembalasan terhadap orang-orang yang memerangi Allah dan Rasul-Nya dan membuat kerusakan di muka bumi, hanyalah mereka dibunuh atau disalib, atau dipotong tangan dan kaki mereka dengan bertimbal balik, atau dibuang dari negeri (tempat kediamannya). Yang demikian itu (sebagai) suatu penghinaan untuk mereka didunia, dan di akhirat mereka beroleh siksaan yang besar." 30

2. Sistem perang dan damai ada pada kategori ini, yakni ketika pelaku tindak kejahatan genosida berasal dari luar negara.

a. Perang

Perang di sini dalam arti memberikan pembalasan kepada mereka sebagai bentuk pertahanan diri. Maka, orang yang mengadakan pelawanan untuk mempertahankan diri ini tidak bisa dijatuhi sanksi. Pendapat ini merujuk kepada firman Allah dalam Al-Qur'an surah Asy-Syura ayat 40-41

b. Damai

Yakni dengan cara melaporkannya ke pengadilan yang berwenang dan menghukumnya sesuai dengan perjanjian yang telah disepakati sebelumnya. Pendapat ini merujuk pada firman Allah dalam surah Al-Hujurat ayat 9.

Bila melihat ketentuan hukum internasional yang mengatur pelaku tindak kejahatan genosida tersebut, ada kesamaan dengan ajaran Islam. Kesamaannya yakni, pelaku tindak kejahatan genosida sama-sama akan dijatuhi hukuman bila sudah cukup memiliki bukti. Namun, ketentuan hukum yang tercantum dalam hukum internasional tentang sanksi terhadap tindak pidana genosida belum cukup sesuai dengan ajaran agama Islam yang mengajarkan adanya qisas dalam tiap tindak pidana pembunuhan, terlebih sanksi yang dijatuhkan kepada bugat. Allah sangat mengecam tindakan pemberontak yang hanya bisa merusak muka 
bumi. Bila dilihat dari Hukum Pidana Islam, sudah sangat jelas bahwa sanksi pidana penjara tidak seimbang bila dibandingkan dengan kejahatan seorang pembunuh, terlebih pelaku tindak kejahatan genosida yang membunuh dan membantai lebih dari satu jiwa. Sudah pasti hukuman mati adalah hukuman yang paling pantas sebagai qisas yang telah dilakukan oleh tersangka.

Pengadilan Internasional yang merujuk kepada perjanjian hukum internasional berupa Statuta Roma memberikan sanksi sesuai dengan peraturan yang tercantum di dalamnya. Apabila dilihat dari segi tersangka, Pengadilan Internasional sudah cukup adil dan bijak memberikan sanksi kepada pelaku tindak kejahatan genosida dengan tidak memandang suku, bangsa, dan juga jabatannya. Semua diperlakukan sama dan dihukum sesuai dengan tuntutan jaksa dan korban.

Sebaliknya, bila dibandingkan dengan hukum internasional Islam, maka hukuman penjara tidak sebanding dengan perbuatan yang telah dilakukan oleh pelaku tindak kejahatan genosida.

Apa yang ada di dalam Statuta Roma merupakan pemecahan masalah yang berlaku untuk seluruh negara pihak di dunia. Meskipun sanksi yang dijatuhkan kepada pelaku tindak kejahatan genosida tidak sesuai dengan ajaran agama Islam, namun negara Islam yang menjadi pihak perjanjian tetap harus mematuhi perjanjian tersebut dan meyakini bahwa perjanjian tersebut dibuat demi kemaslahatan umat sedunia.

\section{Penutup}

Berdasarkan hasil dari pembahasan di atas, maka dapat ditarik beberapa kesimpulan bahwa, tindak kejahatan genosida telah diatur di dalam Statuta Roma dan berlaku secara internasional di dalam ruang lingkup negara-negara yang turut serta dalam perjanjian tersebut. Sanksi bagi pelaku tindak kejahatan genosida tercantum di dalam pasal 77 Statuta Roma, yakni berupa penjara, denda, dan penyitaan. Mengenai ketentuan hukum, ketentuan hukum di dalam hukum internasional yang 
mengatur tentang tindak kejahatan genosida dapat dinilai cukup adil karena Pengadilan Internasional tidak memandang suku, bangsa, dan kedudukan pelaku genosida dalam memberikan sanksi. Sebaliknya, bila dinilai dari fikih dauly, maka sanksi yang ada di dalam hukum internasional dinilai tidak cukup imbang dibandingkan dengan tindakan pelaku genosida.

Tindak kejahatan genosida merupakan tindakan keji yang dilakukan terhadap umat manusia. Oleh karena itu, hendaknya umat Islam tetap berpegang teguh untuk mempertahankan hakhak dan kebebasannya agar terhindar dari tindak kejahatan genosida, serta tetap menta'ati perjanjian dan menghormati perjanjian tersebut sebagai hukum yang dipercaya untuk kemaslahatan secara internasional.

\section{Daftar Pustaka}

Brownlie, Ian. Basic Document on Human Rights. Jakarta: UI Press, 1993.

Departemen Agama RI. Al-Qur'an dan Terjemahnya. Bandung: CV Penerbit Diponegoro, 2006.

Djazuli, A. Fiqh Jinayah. Jakarta: PT. Raja Grafindo Persada, 1997.

------. Fiqh Siyasah: Implementasi Kemaslahatan Umat dalam RambuRambu Syariah. Jakarta: Kencana Prenada Media Group, 2009.

Friedlander, Henry. The Origin of Nazi Genocide. North Carolina: Univ of North Carolina Press, 1997.

ICC-CPI. Understanding the International Criminal Court. Netherlands: Facts sheets, 2011.

International Criminal Court. Rules of Procedure and Evidences. UN, document, 2001.

International Criminal Court. Statuta Roma. Roma, 17 Juli 1998.

International Criminal Court. www.icc-cpi.int, diakses 1 Juli 2013. Isharyanto, Mas. Mengapa ICC Gagal Menangani Konflik Sudan?. http://isharyanto.wordpress.com/racikan-ilmiah/lentera- 
ide/mengapa-icc-gagal-menangani-konflik-sudan/, diakses 1 Juli 2013.

Maududi (al-), Abul A'la. Human Rights in Islam. Jakarta: Bumi Aksara, 1995.

. The Islamic Law and Constitution. Bandung: Mizan, 1995.

Nabhani (an-), Taqiyuddin. Al-Daulah Al-Islamiyah. Bogor: Pustaka Thariqul 'Izzah, 2000.

Ricobain. Pembantaian atau Genosida Terbesar dalam Sejarah. http:www.ricostrada.com/sejarah/pembantaian-atau genosida-terbesar-dalam-sejarah, diakses 28 Maret 2013.

Rizki, Rudi M. Unsur-Unsur Genosida. Yogyakarta, 2005.

Rudy, T. May. Hukum Internasional. Bandung: PT. Refika Aditama, 2006.

Solihat. Hubungan Internasional dalam Figh Siyasah. http://majelispenulis.blogspot.com/2012/05/hubunganinternasional -dalam fiqh.html, diakses 28 Maret 2013.

Spalding, Frank. Genocide in Rwanda. New York: The Rosen Publishing Group, Inc., 2009.

Starke, J.G. Pengantar Hukum Internasional 2. Jakarta: Sinar Grafika, 1997.

Syaibani (al-), Muhammad bin Hasan. Kitab Al-Siyar Al-Saghir. Islamabad: Islamic Research Institute, 1998.

Wicaksono, Ditto. Keberlakuan Konvensi Genosida 1948 Terhadap Kasus Genosida di Turki. http://ditto-w.blogspot.com/2008/11/, diakses 28 Maret 2013.

Wikipedia. Statuta Roma. http://id.wikipedia.org/wiki/StatutaRoma, diakses 16 Agustus 2013. 